\title{
SVIJET DJEČJE KNJIŽEVNOSTI U OSTAVŠTINI ZLATE KOLARIĆ-KIŠUR
}

\section{Sažetak}

Na temelju ostavštine Zlate Kolarić-Kišur, koja se čuva u Zavičajnoj zbirci Possegana Gradske knjižnice i čitaonice Požega, autorica želi ukazati na toliko željeni „povratak“ Zlate Kolarić-Kišur u Zlatnu dolinu, naravno kroz predmete i građu koju je Gradska knjižnica i čitaonica Požega zaprimila kao izdvojeni dio Zavičajne zbirke. Budući da ostavština sadrži fotografije, osobne predmete, dio knjižnice, njezina autorska djela, hemeroteku članaka vezanu uz njezina djela i rad, rukopise - objavljene i neobjavljene, korespondenciju, osobne dokumente cijele obitelji, autorica se odlučila za prezentaciju onog dijela ostavštine koji je povezan s dječjom književnošću. Kao prvo osvjetljava motiv - kada je i zašto Zlata Kolarić-Kišur počela pisati za djecu, zatim razotkriva ishodište njezina cjelokupnog stvaralaštva za djecu - a to je osebujno djetinjstvo u Požegi, u Zlatnoj dolini - te predstavlja sva njezina djela napisana za djecu koja su kao ostavština dio Zavičajne zbirke Possegana. Iz vrlo bogate hemeroteke izdvaja one članke koji se odnose na njezin književni rad s djecom. Također podsjeća na tekstove Zlate Kolarić-Kišur koji su uglazbljeni. Važan segment ovog rada jest i uloga Zlate Kolarić-Kišur u odgojno-obrazovnom kontekstu, tj. zastupljenost njezinih tekstova u školskim udžbenicima, časopisima i novinama za djecu. Autorica izdvaja i dio ostavštine koji je vezan uz komunikaciju Zlate KolarićKišur sa svojim malim, ali i velikim čitateljima. Ta komunikacija bila je odlična, djeca su je obožavala, a ona, unatoč svojim poznim godinama, nije izgubila kontakt sa svojim malim čitateljima. Zlata Kolarić-Kišur bila je profesionalna književnica, a zahvaljujući sačuvanim dokumentima, autorica progovara i o položaju pisaca u vremenima u kojima je radila, tj. pisala.

Ostavština Zlate Kolarić-Kišur, koju čuva Gradska knjižnica i čitaonica u Požegi, kao neprocjenjivi izvor informacija o životu i djelu Zlate KolarićKišur, vrijedna je baština koja je dostupna svima, ali da potpuno bude vidljiva, potrebno ju je digitalizirati.

Ključne riječi: Zlata Kolarić-Kišur; dječja književnost; Požega; ostavština; Gradska knjižnica Požega; Zavičajna zbirka; djetinjstvo u Požegi; korespondencija; hemeroteka. 


\section{Uvod}

Svaka knjižnica svoj fond neprestano nadograđuje, a nabava u pojedinim knjižnicama ovisi o vrsti knjižnice, već postojećem fondu, ali i financijskim sredstvima kojima raspolaže. No jako je važno da i sama knjižnica ima neka svoja pravila ili smjernice $^{1}$ za nabavu. Tako je jedan od vrlo čestih načina nabave u Gradskoj knjižnici i čitaonici Požega dar, ali i primanje na dar cijelih ostavština nakon smrti naših zavičajnika. ${ }^{2}$ Darovi mogu biti netraženi (ponuđeni), što je slučaj s gotovo svim ostavštinama koje su u našu Knjižnicu stigle željom darovatelja, ali i traženi, ako knjižnica sama zatraži određenu građu. Ostavštine, u kojima se često nalaze i cijele knjižnice, važan su segment u izgradnji svake knjižnične zbirke, ali i dragocjena baština koju knjižnice čuvaju i daju na korištenje.

Ostavštinu Zlate Kolarić-Kišur Knjižnica nije zatražila nego nam je 2007. godine iznenada dovezena u nekoliko kutija, s obrazloženjem da je to bila želja Zlate Kolarić-Kišur. Dakle, Knjižnica nije u posjedu nikakve oporuke ili ugovora kojom bi bila potvrđena primopredaja nego je preuzela sve dovezeno,jer nitko od obitelji nije bio zainteresiran za to. To znači da je preuzeto sve, pa i nepotrebna građa koja nam nije značajna za zbirku (računi za struju, uplatnice za vodu i slični dokumenti), a koju bismo bili, da smo mogli pregledati građu prije, vjerojatno preusmjerili nekoj drugoj ustanovi. Knjižnica je ostavštinu prihvatila i, s obzirom na okolnosti, građa je razvrstana i samo popisana, ${ }^{3}$ jer nam za sređivanje tako velike ostavštine nedostaje stručni kadar, koji bi uz stručnu obradu odmah i digitalizirao zbirku. Naravno, digitalizacija još nije započela, ali cjelokupna ostavština dostupna je našim korisnicama za znanstvena istraživanja, izložbe, seminarske radove itd.

\section{Povratak Zlate Kolarić-Kišur u Zlatnu dolinu}

Zlata Kolarić-Kišur nije rođena u Požegi, ali njezini su se roditelji vrlo brzo tamo preselili. Svoje prve korake Zlata je učinila upravo u Požegi, tamo provela djetinjstvo i mladost do udaje, i to tako intenzivno i veselo da je nakon odlaska uvijek čeznula za Požegom, ne samo kroz sjećanja koja je opisala u knjizi Moja Zlatna dolina, već je uvijek željela i stvaran povratak u "svoju dolinu djetinjstva“. Smatram da se to i dogodilo. Zlata Kolarić-Kišur umrla je u Zagrebu 1990. godine, pokopana je na Mirogoju i sedam godina kasnije cijeli njezin život „stao je u desetak kutija“ i vratio se u ulicu Zlatina djetinjstva - Kanižlićevu, ovaj put ne u Grabrik, gdje je nekad živjela, nego u Gradsku knjižnicu i čitaonicu Požega. Bilo je tužno gledati kako jedan

1 Smjernice za nabavu knjižnične građe u Gradskoj knjižnici i čitaonici Požega od 17.3.2014.

2 Gradska knjižnica i čitaonica Požega čuva ostavštine Julija Kempfa, Franje Cirakija, Josipa Pavičića, Ivše Bošnjaka-Dragovačkog i Ljube Kuntarića

3 Popis ostavštine Zlate Kolarić-Kišur. Popis sastavila Marija Zubić, 4.12.2009. 
dug (96 godina), bogat i sadržajan život stane u nekoliko kutija. Ali, s druge strane, sadržaj kutija sve nas je oduševio, jer ostavila nam je svima najveći kapital - pisanu riječ, koja je i danas s nama, a da ne govorim o fotografijama, rukopisima, korespondenciji, uglazbljenim djelima, knjigama, pa i malom plavom čuperku njezine kćeri Vesne, hemeroteci novinskih članaka...

Treba spomenuti da je 1969. godine na zamolbu dr. Đure Kuntarića poslala dio fotografija i bilješke o sebi koje se nalaze u Gradskom muzeju. ${ }^{4}$

\section{Svijet dječje književnosti Zlate Kolarić-Kišur}

Zlata Kolarić-Kišur u Požegi je završila višu djevojačku i žensku stručnu školu, a za vrijeme Prvoga svjetskog rata, u okviru Crvenog križa, kao bolničarka, služila je u požeškoj bolnici i vidjela sve ratne strahote. ${ }^{5}$ Osim male epizode iz djetinjstva, kada je napisala jednu šaljivu pjesmicu, nikad nije pomišljala na pisanje. I onda ju je bolest kćeri Vesne pokrenula da joj priča svoje priče i govori svoje pjesmice. Ljepota, radost, veselje, iskrenost, igra i pjevanje vratili su je u djetinjstvo i pokrenuli osjećaje koje je prenosila na papir i razveseljavala mali dječji svijet.

Njezine knjige za djecu koje smo dobili u ostavštini odlično su sačuvane, nekih ima po više primjeraka, ali posebna su vrijednost posvete na naslovnicama: Zlata Kolarić-Kišur: Iz dječjeg kutića. Tisak i naklada knjižare St. Kugli, Zagreb, Ilica 30. a na naslovnoj je stranici posveta: Svojoj dragoj kćerkici na spomen na prve lijepe dane djetinjstva, napisala mama. Zgb., prosinac 1935. A na knjizi Smijte se djeco, Tisak i naklada knjižare St. Kugli, Zagreb, Ilica 30, - napisala je: Draga djeco! Neka Vam pod geslom ove knjige prolazi cijeli život! Neke knjige samo je potpisala - Zlata KolarićKišur: Crni brigadir, izdanje glavnog odbora A.F.Ž. Hrvatske, Zagreb, 1947. U knjizi Zlata Kolarić-Kišur: Dobra majka. Djeca o majci. Tisak i naklada S. Kugli, Zagreb, Ilica 30, nalaze se i njezini komentari na marginama. Ta prva izdanja uključuju pjesmice i igre, ali sačuvan je i primjerak Zimske priče, Zagreb: Novo pokoljenje, 1950., koji je napisala prema istoimenu igrokazu iz 1938., u kojoj autorica vješto spaja izmišljeno i doživljeno, uz izmjenjivanje proze i stiha. Vrlo je rijedak i primjerak slikovnice Od zore do mraka u izdanju Ministarstva Narodnog zdravlja Narodne Republike Hrvatske, 1950.

4 Gradski muzej Požega. Zlata Kolarić-Kišur FA 126

5 Ostavština Zlate Kolarić-Kišur u Gradskoj knjižnicii čitaonica Požega (Prvi svjetski rat) 

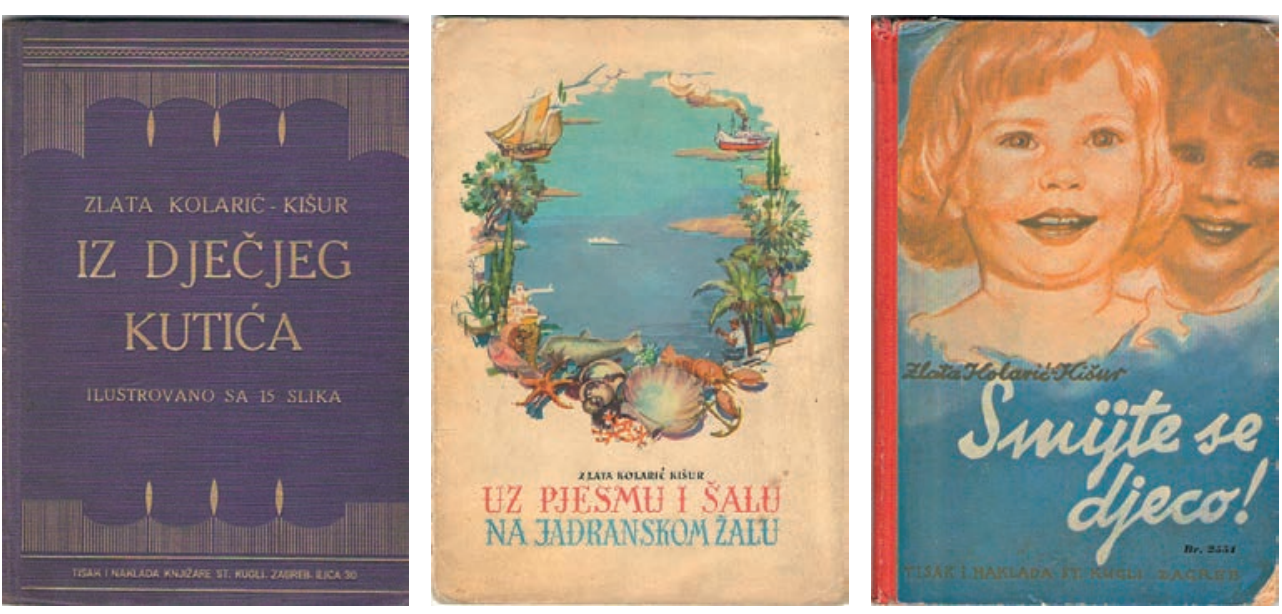

Uz djeci prihvatljive crteže Nade Doroški, ta edukativna slikovnica djecu upućuje u tjelovježbu, igru, higijenu, zdravu prehranu. Danas sačuvana u malo primjeraka jest i slikovnica Dječje igre u izdanju Naše djece iz Zagreba, 1963. Slikovnica je posebno zanimljiva djeci jer ju je ilustrirao Vladimir Kirin, a na naslovnici opet ima potpis - mama. I onda jedna mala biser-knjiga pod nazivom Cvijeće u izdanju Naklade Color iz Zagreba 1955. godine gdje je, opet uz prekrasne ilustracije cvijeća Vladimira Kirina, autorica ispričala priče o cvijeću i ljepoti. Također jedna vrlo rijetka slikovnica jest Uz pjesmu i šalu na Jadranskom žalu u izdanju Naše djece iz Zagreba, 1961. godine, koju je ilustrirao Oto Antonini. Autorica nas vodi na more i kao mali putopis uz realistične Antoninijeve ilustracije uranjamo u ljepote Jadranskog mora. Dolazimo do novijih slikovnica kao Moje radosti, koju je priredio Joža Skok, a ilustrirala Danica Rusjan u izdanju Naše djece 1981. Slikovnica je paralelno tiskana i u slovenskom prijevodu, koji na naslovnici ima posvetu: Dragoj Vesni i Rudiju - mama! Te su slikovnice vrijedne jer su izdanja vrlo rijetka, ali pjesme, bez obzira na to što pripadaju zlatnom dobu nazorovskog romantizma, još uvijek privlače djecu. ${ }^{6}$ I onda slijede brojna izdanja najpoznatije knjige Moja Zlatna dolina, ali najviše primjeraka šestog izdanja. To je jedna od najljepših knjiga o djetinjstvu, i to o sretnom djetinjstvu. Kao lektirno štivo knjigu su pročitale tisuće djece i upoznale se s požeškom „zlatnom dolinom djetinjstva“. U toj knjizi susrećemo se i s dokumentarnim elementima u susretima naše junakinje sa značajnim osobama iz kulturnog života Požege: Dragutin Lerman, Franjo Ciraki, August Harambašić, A. G. Matoš, slikar Miroslav Kraljević i Vladimir Becić. Događaj s Miroslavom Kraljevićem koji je opisan u knjizi

$\overline{6}$ Cvitan, Dalibor. Zlatni romantizam u željeznom dobu. Umjetnost $i$ dijete, godina VI, br. 33 , str. 13 
pomogao je da se identificira djevojčica s novootkrivene slike M. Kraljevića: Djevojka u naslonjaču, ulje na platnu iz 1911. Na slici je upravo Zlata Kolarić-Kišur. ${ }^{7}$

U ovom svijetu dječje književnosti Zlate Kolarić-Kišur važno mjesto zauzimaju i njezini kazališni izričaji za djecu: Nadina velika tajna - dječji igrokaz, prikazan u zagrebačkom HNK 1934., u kojem je glumila i mala Lea Deutsch. U ostavštini su sačuvane brojne pozivnice, pozivi na predstave, programi za više scenskih prikaza za škole, često s pjevanjem i plesom. Zagrebačko, Splitsko i Zadarsko lutkarsko kazalište izvodilo je njezinu lutkarsku igru Hrabri miš i pustolovni vitezovi (1954. - 1968.), a Pionirsko kazalište u Zagrebu izvelo je Kristalne zvončiće (1952.). Okušala se i u radiodrami, posebno za djecu.

\section{Rukopisi}

U ostavštini su poseban dio i rukopisi, zaprimljeni u pomalo nesređenom stanju (pomiješani), ali za ovu prigodu izdvojila bih baš rukopis priče Graja iz Moje Zlatne doline, zatim pjesme Pred odlaskom, Ljepota na stazama života, zatim rukopis igrokaz za malu djecu u tri slike: Pismo svetom Nikoli.
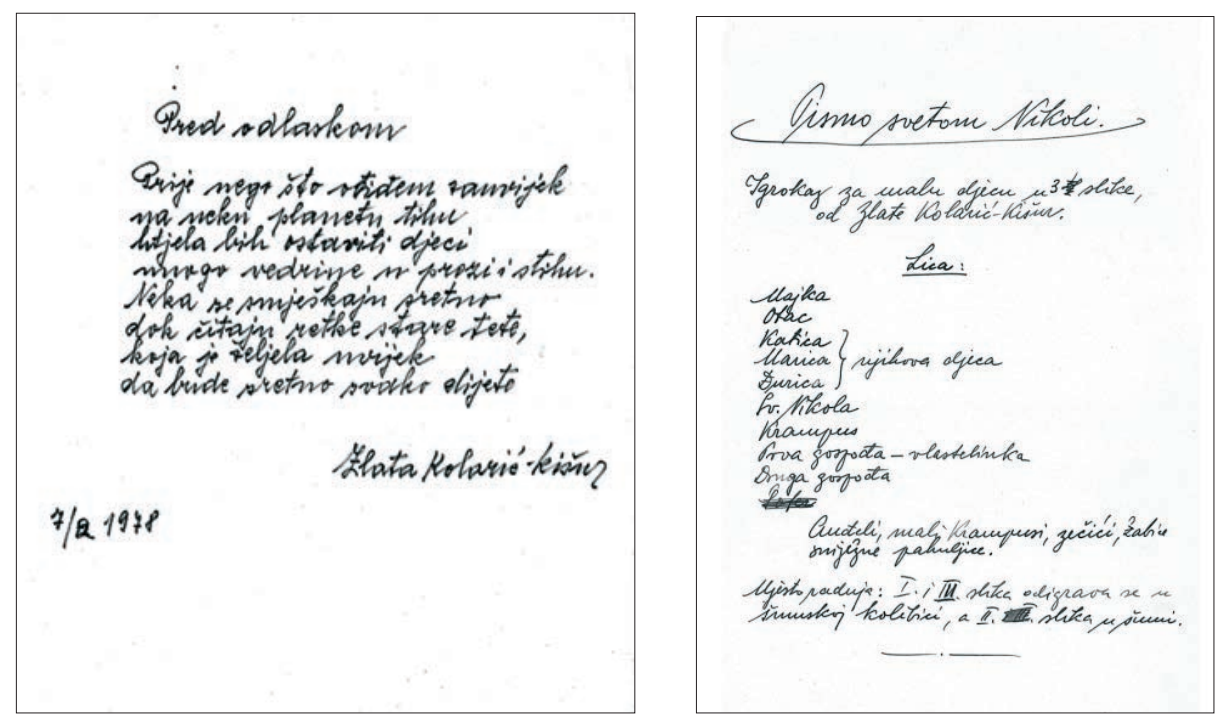

Naravno da je sva ostala građa pisana pisaćom mašinom: radiodrame za djecu koje su emitirane na Radio Zagrebu. Dio ih je i neobjavljen i svakako treba izdvojiti taj dio.

$\overline{7}$ Nepoznati Kraljević: nikad viđeno djelo prvi put pred javnošću. Večernji list, 7.9.2013. 


\section{Fotografije}

Dragocjen izvor za proučavanje književnog djela za djecu i života Zlate KolarićKišur jest i njezina ostavština fotografija, koju smo također zaprimili u cijelosti. Kako u knjizi Moja Zlatna dolina postoji i poglavlje Rastanak sa Zlatnom dolinom, ja bih tu cjelokupnu ostavštinu, a posebno fotografije, nazvala Zlatin povratak u Zlatnu dolinu. Za ovu temu ukazala bih na izuzetno vrijedne prve Zlatine fotografije u Požegi. Uglavnom su to obiteljske fotografije velikih i malih formata (Zlata kao djevojčica), a fotografi su zagrebački, osječki, ali i požeški. ${ }^{8}$ Zatim su tu vrlo dobro sačuvane fotografije Zlate iz požeških školskih dana, djevojaštvo (uočljiva je odjeća sa šeširima i suncobranima) sve do udaje (slika s vjenčanja s Hinkom Kolarićem-Kišurom). I kroz te fotografije osjećamo sreću i ljepotu Zlatina požeškog djetinjstva i mladenaštva. No, ono što zadivljuje jest velik broj fotografija (pojedine u više primjeraka) sa kćeri Vesnom - od rođenja pa do posljednjih trenutaka. U ovoj zbirci možemo čak izdvojiti posebne Vesnine albume u kojima su fotografije kronološki složene, od rođenja do poznih godina. Kolika je to bila majčina ljubav, dokazuje i sačuvan plavi čuperak Vesnine kose.

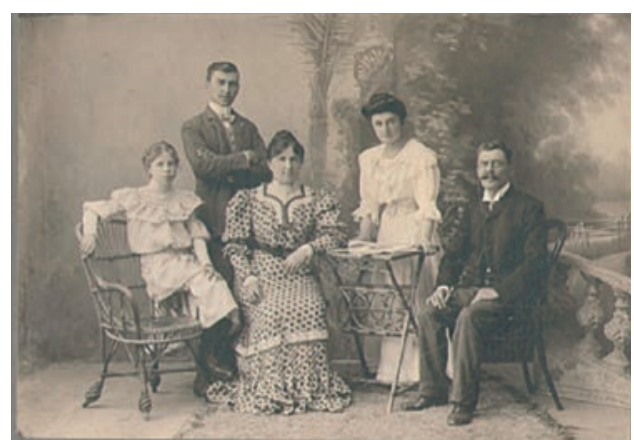

Slika 1. Obitelj Hadžija u Požegi, 25. 06.1906. (Zlata prva s lijeve strane). Atelier Wollner, Požega, Kamenita vrata 7.

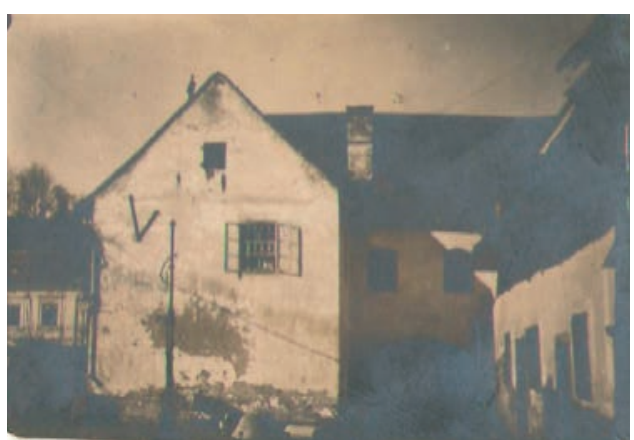

Slika 2. Grabrik - dvorište i kuća Zlate KolarićKišur u Požegi u Kanižlićevoj ulici

Naravno, dio te ljubavi, kroz svoje pjesme i priče, prenosila je i drugoj djeci možemo reći da je razlila ocean ljubavi, sreće i prijateljstva. Kod fotografija uočljive su uglavnom obiteljske fotografije, tek je vrlo mali broj fotografija iz javnog i društvenog života, a to samo govori koliko je Zlata uživala u sreći obiteljskog života, slobodno možemo reći, do posljednjeg dana. Postoji, dakle, kronološki slijed fotografija koji precizno prati život Zlate Kolarić-Kišur, koji je bio iznimno sadržajan i dug, jer je doživjela 96 godina. No s obzirom na velik broj fotografija šire rodbine, za potrebe digitalizacije bit će potrebno izvršiti izbor fotografija.

\footnotetext{
8 Julije i Cecilija Davidson „, Atelier Wollner“. Požega, Kamenita vrata 7
} 


\section{Hemeroteka}

Svaka knjižnica koja ima Zavičajnu zbirku marljivo skuplja i, u novije vrijeme, digitalizira članke iz novina vezane uz zavičajne teme. A u ostavštini Zlate KolarićKišur pronašli smo i vrijednu zbirku isječaka iz novina, časopisa u kojima su bile zabilježene kritike o izdanjima njezinih knjiga, najave njezinih kazališnih komada za djecu, objave njezinih pjesama, priča i igrokaza u raznim novinama i časopisima za djecu, ali ne samo za djecu nego i npr. Vjesniku - na stranici ili kutiću posvećenima djeci. Lijep je to izvor informacija, uglavnom pozitivnih kritika. Zlata Kolarić-Kišur marljivo je izrezivala te članke i objave pjesama u Vjesniku u srijedu, Narodnom listu, Vjesniku, Školskim novinama, Ženskom listu, Svijetu, u časopisu Obitelj, Modroj lasti, Smibu, Radosti... Npr. Ivo Kozarčanin kritiku knjige Priča i zbilja u Hrvatskom dnevniku na 14. str. završava sljedećim riječima. „Mislim, da natpis knjige Priča i zbilja nije najsretniji, jer djeluje više didaktički, nego umjetnički. To je svakako ono najslabije u knjizi."
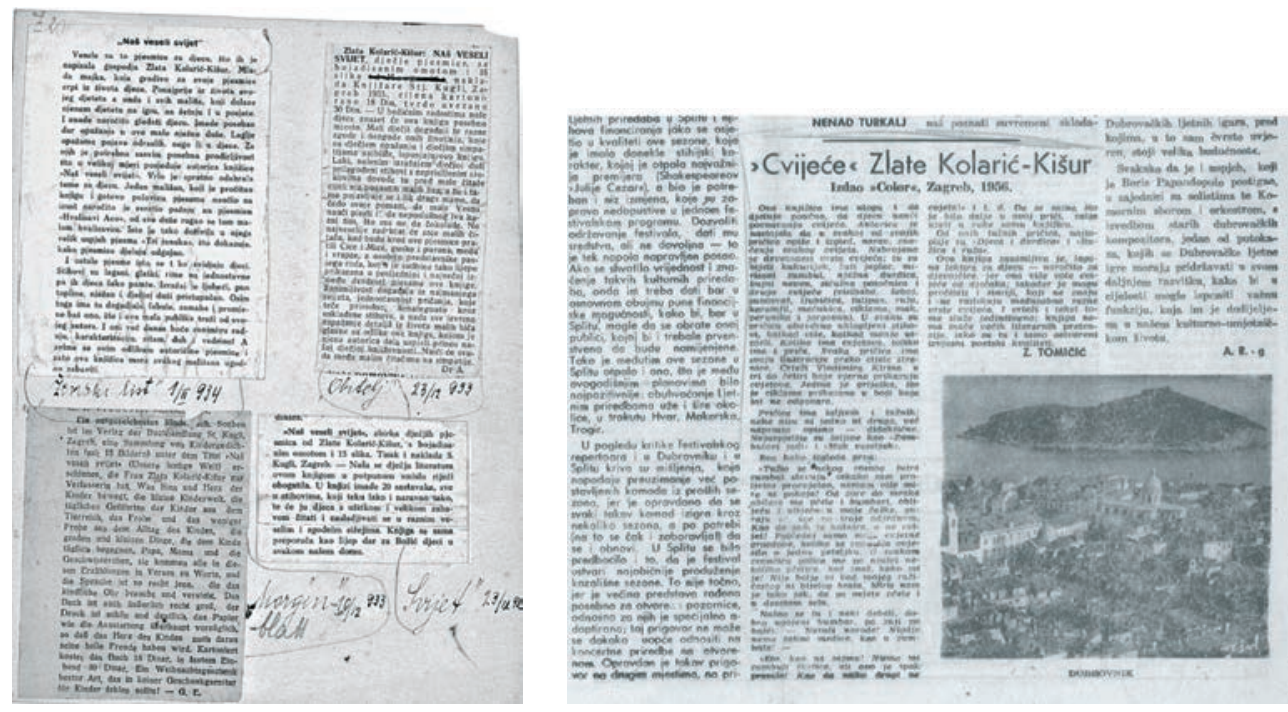

Zlata Kolarić-Kišur znatiželjno je pratila sva kulturna događanja, pa je reagirala i člankom u časopisu Modra lasta na spomen glumice Mile Dimitrijević. ${ }^{9}$ Ili, također u Modroj lasti, objavila je pjesmu Pjesnikove oči posvećenu Grigoru Vitezu u povodu njegove smrti 23.11.1966. ${ }^{10}$

\footnotetext{
9 Modra lasta, 15.2.1972., str. 20

10 Modra lasta, br. 10. (1966), str. 3
} 


\section{Uglazbljeni tekstovi Zlate Kolarić-Kišur}

Činjenica je da su djeca voljela slušati, ali i čitati Zlatine pjesme, posebno one kraće, koje su bile gipke i lako pamtljive. I logično je da su ih djeca rado i pjevala, jer doista, puno je Zlatinih pjesama uglazbljeno. Budući istraživači ostavštine Zlate Kolarić-Kišur bit će impresionirani sačuvanim Zlatinim uglazbljenim tekstovima. Npr. izdanje Muzičke naklade - Zagreb: Lovro Županović: Pjesmice o cvijeću Janičino najmilije cvijeće, dječji zbor iz klavir. Zatim, J. Kaplan: Na sunčanoj stazi - ciklus pjesama za dječji zbor ili solo glas uz klavir, također u Muzičkoj nakladi - Zagreb. Pjesme je uglazbio i Nikša Njirić: Golubi i sova, Gledajte me, Željica, Uspavanka. Također Nikša Njirić uglazbio je tekst slikovnice Uz pjesmu i šalu na Jadranskom žalu. Note su objavljivane u izdanju Saveza muzičkih društava Hrvatske. Sačuvane su uglazbljene Zlatine pjesme u Zborniku dječjih i omladinskih pjesama u izdanju Muzičke naklade Zagreb; Pero Gotovac: Najmlađa brigada - dvoglasni dječji zbor i klavir i Moja lutka - troglasni dječji zbor i klavir. Za Djeca pjevaju 75 - za Dan dječje radosti, tekst Zlate Kolarić-Kišur uglazbio je Mario Bogliuni. Prava dragocjenost u glazbenoj ostavštini Zlate Kolarić-Kišur riječi su pjesme Po dragim stazama, koje je uglazbio Milivoj Radović prigodom prvoga slavonskog muzičkog festivala Slavonija 69 i proslave 270-godišnjice Gimnazije u Slavonskoj Požegi 1699. - 1969., a note su izdali bivši đaci požeške Gimnazije. No sačuvane su i note, tj. glazba za istu pjesmu, koju je skladao naš zavičajnik Ljubo Kuntarić. A na natječaju Djeca Zagreba pjevaju Zlatinu pjesmu Kličem suncu uglazbio je Z. Šebetić (objavljeno u Ritmu 4, popularne plesne melodije).

Sve te pjesme dokazuju da je bilo veselo uz Zlatu Kolarić-Kišur. A da se radi o kvalitetnoj glazbi, dokazuje i to što su navedene pjesme uvrštene u školske udžbenike: Vladimir Tomerlin: Radost u pjesmi - udžbenik za muzički odgoj u V. i VI. razredu osnovne škole. Zagreb: Školska knjiga, 1961. Višnja Manasteriotti: Zbornik pjesama i igara za djecu - priručnik muzičkog odgoja. Zagreb: Školska knjiga, 1971.
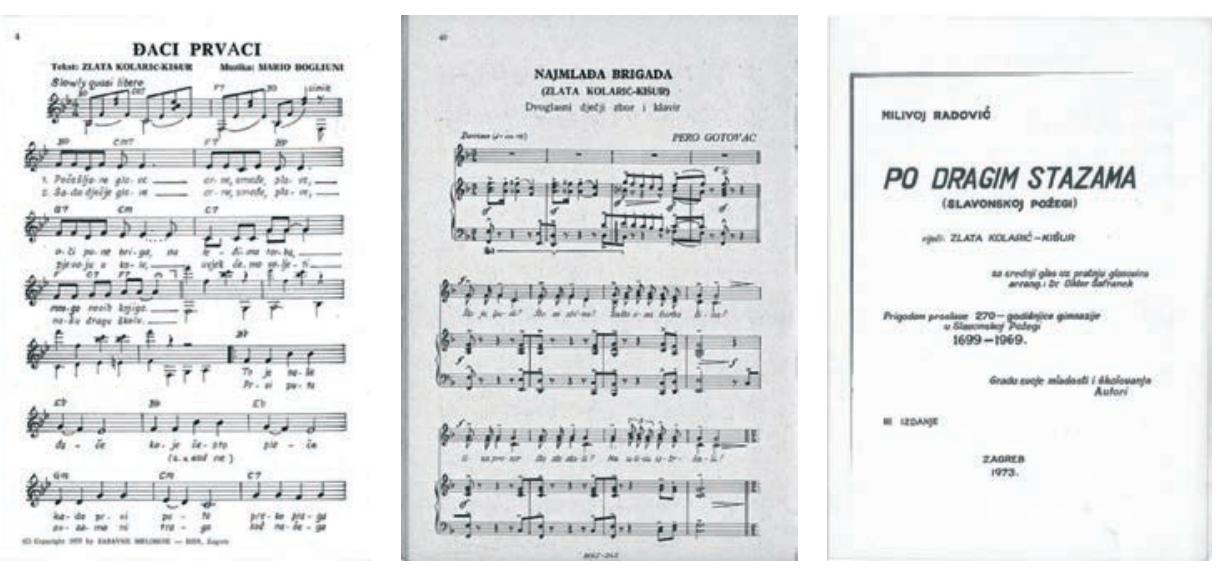


\section{Odgojno-obrazovni kontekst}

Kada se 1919. godine Zlata Hadžija udala za prvu i jedinu ljubav - Hinka Kolarića-Kišura, a i napustila Požegu i Zlatnu dolinu u kojoj je završila Žensku srednju stručnu školu i Višu djevojačku, nije ni slutila da će u Zagrebu uroniti u svijet književnosti, posebno onaj posvećen djeci. Počelo je neprofesionalno, slučajno, usmenim pričama kćeri Vesni. Objavljivanje u novinama zapalilo je iskru sjećanja na djetinjstvo u Zlatnoj dolini, a njezina blagost i dobrota isijavala je posebnu energiju koju su djeca upijala i zajedno sa Zlatom uživala u tim toplim, veselim, razigranim riječima. Doživjela je duboku starost, umrla je u 96. godini, što znači da je živjela u različitim državama, ali njezino „dječje pismo“ uvijek je nalazilo put do djece i do izdavača. Jednostavnost izričaja, ljepota riječi, nenametljive poruke dolazile su do dječje svijesti bez prisile i, ono što je najvažnije, uvijek je tu bila ljubav, obitelj, dobrota, domovina, prijateljstvo... U ostavštini nalazimo udžbenike za osnovnu školu u koje je uvrštena pisana riječ za djecu: svakako treba spomenuti Vrtuljak riječi - čitanku iz književnosti za drugi razred osnovne škole, autorice Dubravke Težak, u izdanju Znanja iz Zagreba, 1998., u koju je uvrštena i pjesma Uspavanka na moru. I godinu dana kasnije udžbenik Lucije Puljak, Radost plovidbe, čitanka za III. razred osnovne škole, u koji je uvrštena pjesma Riječi. Naravno, sve su pjesme metodički obrađene. No najveći utjecaj imala je knjiga Moja Zlatna dolina i njezina metodička obrada u mnogim udžbenicima, a posebno ističem čitanku za IV. razred osnovne škole, autora Diklić - Skoka: Djetinjstvo u Zlatnoj dolini, koji je čak naslovljen prema Zlatinoj knjizi i koji, naravno, razotkriva vrijednosti djetinjstva na primjeru teksta iz knjige Moja Zlatna dolina. Zlata Kolarić-Kišur radovala se objavljivanju svojih pjesama i priča u časopisima, zbornicima, udžbenicima i knjigama, a sve objavljeno marljivo je čuvala.
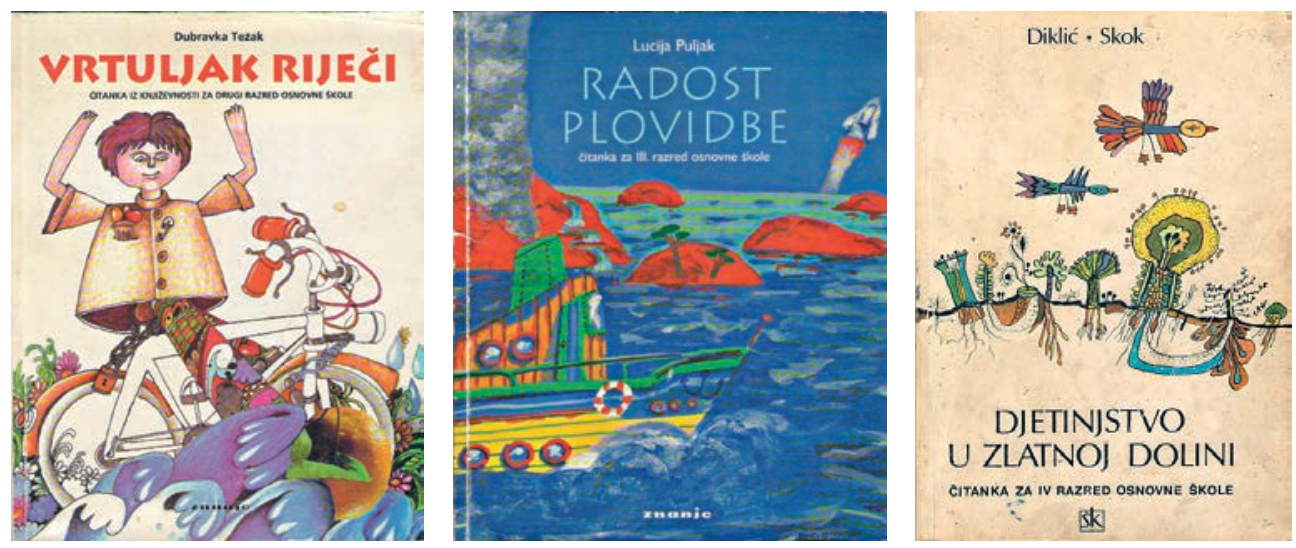
No interes za knjigu Moja Zlatna dolina ne prestaje ni danas. Tako smo u ostavštini evidentirali i tri diplomska rada, od kojih je jedan i naše Požežanke Ines Hamžik. Interesantno, nema puno fotografija s književnih susreta, ali sačuvana je iznimno bogata korespondencija s malim i velikim obožavateljima. Dobar dio te korespondencije dokazuje da su je djeca jednostavno voljela. No interes za njezine slikovnice ne prestaje. Grad Požega 2012. godine izdao je pretisak slikovnice Zekini jadi, čije su prvo izdanje 1989. objavila Naša djeca. A Drago Kozina iz Naše djece traži dopuštenje da pjesmu Moj zeko objavi kao taktilnu slikovnicu. Tako je u našu zavičajnu zbirku ušla i ova mala, vesela slikovnica. O interesu Zlate Kolarić-Kišur za književnost, ne samo dječju, nego i svjetsku, zatim umjetnost i pedagogiju svjedoči i dio preuzete obiteljske knjižnice. ${ }^{11}$

\section{Položaj književnice za djecu u kontekstu vremena}

Ovaj naslov namjerno sam izvukla, jer treba spomenuti i položaj Zlate KolarićKišur kao književnice, posebno kao književnice za djecu. Zahvaljujući njezinoj sistematičnosti i svakako vrijednoj osobini čuvanja dokumenata, u ostavštini smo zatekli sačuvane ugovore s izdavačima (Mladost, Hrvatska radiotelevizija, časopis Smib) te izvještaje o prodanim primjercima radi obračuna autorskog honorara. Iako je u svojim intervjuima napominjala da joj je najgori dio posla suradnja s izdavačima i naplata autorskog honorara, isplate su bile uredne, ugovori su se poštivali i svi ti dokumenti potvrđuju urednu isplatu honorara. Naravno, sačuvan je i dio korespondencije s urednicima izdavačkih kuća s kojima je surađivala; dopisivanje s Blankom Dovjak-Matković, urednicima Smiba i dr. Bila je jedna od osnivačica Društva hrvatskih književnica 1936. godine, a od 1945. članica je Društva književnika Hrvatske. Dakle, kada govorimo o Zlati Kolarić-Kišur, govorimo o profesionalnoj književnici čija se pisana riječ poštivala, nagrađivala i objavljivala, a kazališni komadi izvodili i na pozornici HNK, i to unatoč promjenama država i režima. Sigurna sam da je ovakav položaj zaslužila svojom blagošću i dobrotom, iskrenošću i nevjerojatnom količinom ljubavi za djecu, ali i za sve bližnje.

$\overline{11}$ Popis ostavštine Zlate Kolarić-Kišur - popis knjiga iz knjižnice Zlate Kolarić-Kišur 


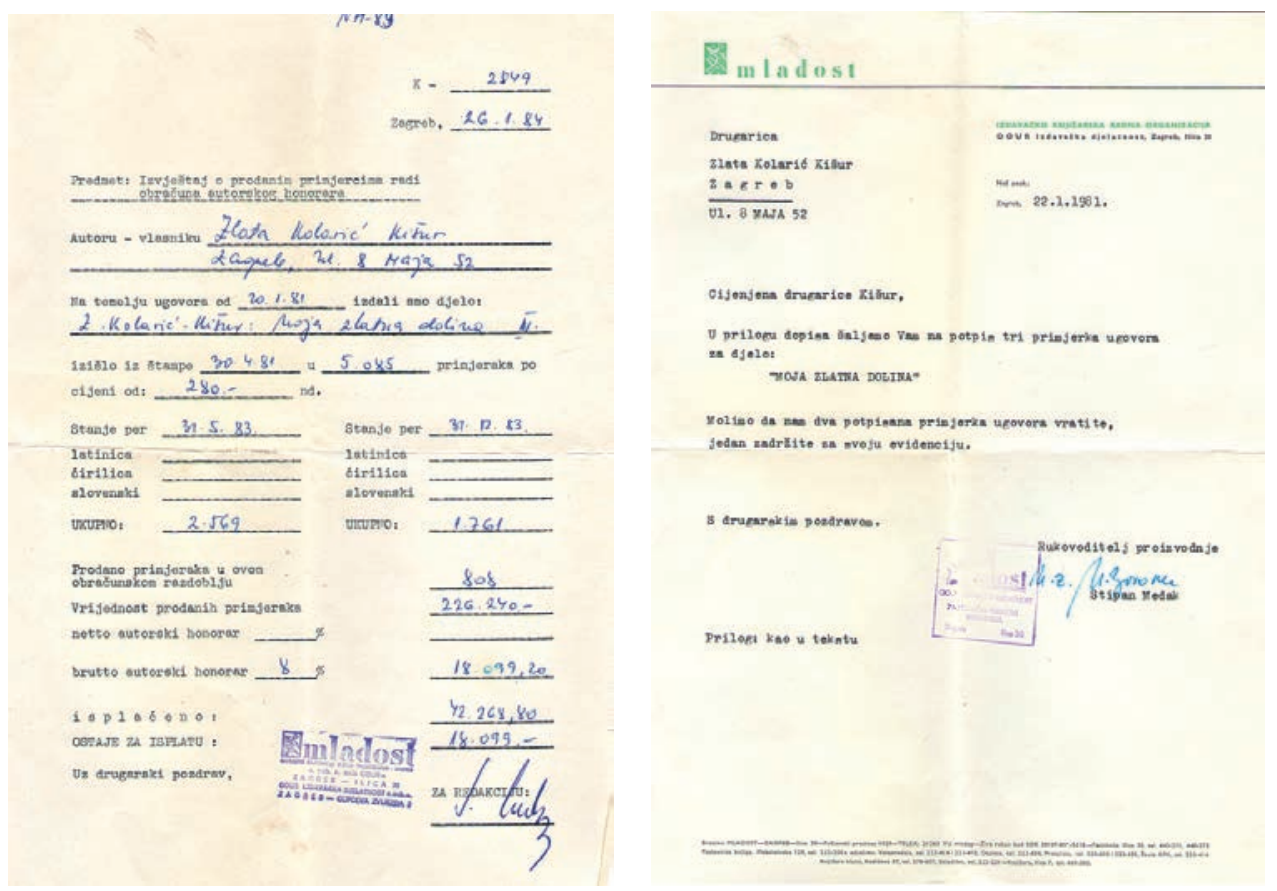

\section{Zaključak}

Izložila sam samo segment bogate i vrijedne ostavštine Zlate Kolarić-Kišur koji se odnosi na njezinu povezanost s dječjom književnošću. No, budući da smo ostavštinu preuzeli u cijelosti, ipak će biti potrebno izlučiti materijal koji nam nije potreban za Zbirku, zatim izlučiti duplikate i pripremiti građu za digitalizaciju.

Ostavština Zlate Kolarić-Kišur svjedoči o kontinuitetu pisanja od 1933. godine, i to bez zabranjivanja ili skrivanja rukopisa. Jednostavno, bio je to bogat, dug i sretan život jedne dobre žene koja je doživjela mnoge nezaboravne susrete i kao bolničarka u Prvom svjetskom ratu, ali i kao književnica u susretima s djecom i mladima. Bogata hemeroteka, fotografije, korespondencija, rukopisi, osobni predmeti i još puno toga čine njezin život i rad živim i dostupnim. Nije mogla ni sanjati da će dom njezine ostavštine biti u istoj ulici u kojoj je provela djetinjstvo, u Kanižlićevoj ulici, samo nekoliko kuća od „najljepšeg dvorišta na svijetu“ - Grabrika.

Završetak uređenja Gradske knjižnice i čitaonice Požega podrazumijeva i odgovarajući smještaj svih ostavština koje se nalaze u zavičajnoj zbirci Possegana, a u posebnu sobu bit će smještena ostavština Zlate Kolarić-Kišur. Bit će to prostor koji će zračiti vedrinom i optimizmom, baš kao što je i njezin život bio velika vedrina i radost koje je nesebično dijelila sa svima, a posebno najmlađima. 


\section{Literatura}

Belan-Simić, Alemka (2006/2007), Baština u narodnim knjižnicama: rezultati ankete. Muzeologija, (43/44), str. 83-92.

Darovi za zbirke: smjernice za knjižnice. Upute za izradbu smjernica za izgradnju knjižnične zbirke primjenom modela Conspectus. Međunarodna posudba i dostava dokumenata: načela i smjernice za postupanje. Model nacionalnog pravilnika za međuknjižničnu posudbu. (2010). Prevele Jelica Leščić, Zagorka Majstorović, Vesna Golubović. Zagreb: Hrvatsko knjižničarsko društvo, str. 12.

Leksikon hrvatskih pisaca (2000), autor koncepcije Krešimir Nemec. Zagreb: Školska knjiga, str. 359.

Kuntarić, Đuro (1970), Zlata Kolarić-Kišur: o njenoj 75-godišnjici. U Požeški zbornik (3). Slavonska Požega: Matica hrvatska - Pododbor Slav. Požega, 175-181.

Miović-Kočan, Stjepo (1985). Vallis aurea kao sjećanje na raj. Umjetnost i dijete, XVII (1), str. 102- 113.

Težak, Dubravka (1991), Hrvatska poratna dječja priča. Zagreb: Školska knjiga, str. 46-48.

Vlašić, Vesna (2012), Ostavština Zlate Kolarić-Kišur u Gradskoj knjižnici i čitaonici Požega. Knjižeona revija: časopis za književnost i kulturu, God. 52., (1), str.17-25.

Zalar, Ivo (1991), Hrvatski dječji pisci III. Zagreb: Nakladni zavod Matice hrvatske, str. 53-58. 


\section{The World of Children's Literature in Zlata Kolarić-Kišur's Inheritance}

\section{Summary}

Based on Zlata Kolarić-Kišur's inheritance collection, which is kept in the Possegana Heritage Corpus at the Požega Public Library, the author aims at pointing out to the greatly desired "return" of Zlata Kolarić-Kišur to the Golden Valley, through items and library corpus that the Požega Public Library had received as a separate part of the Heritage Corpus. Since the inheritance collection contains photographs, personal items, a part of Kolarić-Kišur's library, her copyrighted works, press clippings about her works and activity, manuscripts both published and unpublished, personal correspondence and family documents, the author of the paper decided to present the part of the collection related to children's literature. She first explains the motive (when and why Zlata Kolarić-Kišur started to write children's literature), the origin of all of her creative work for children - her childhood in Požega in the Golden Valley, and subsequently presents all of her literary works for children, which form a part of the Possegana Heritage Corpus through the inheritance collection. The author also extracts articles referring to her literary work for children from a very rich newspaper and periodicals library. She reminds of Zlata Kolarić-Kišur's texts that have been set to music. An important segment of this paper is Zlata Kolarić-Kišur's role in the educational context, i.e. the representation of her texts in schoolbooks and children's magazines and newspapers. The author further highlights the part of the collection related to Kolarić-Kišur's communication with her audience, both young and grown-up. She was a professional writer, and thanks to the preserved documents, the author speaks about the status of writers in the period when Kolarić-Kišur worked and wrote.

Zlata Kolarić-Kišur's inheritance collection, which is kept in Požega Public Library as a valuable source of information on her life and work, presents precious inheritance available to all. However, in order to make it completely visible, it should be digitized.

Keywords: Zlata Kolarić-Kišur; children's literature; Požega; inheritance; Požega Public Library; Possegana heritage; childhood in Požega; correspondence; newspaper and periodicals library.

Jasenka Bešlić, prof. / viša knjižničarka

Gradska knjižnica i čitaonica Požega

Antuna Kanižlića 1, 34000 Požega

jasenka@gkpz.hr 